\title{
A millennial summer temperature reconstruction for northeastern Canada using oxygen isotopes in subfossil trees
}

\author{
M. Naulier ${ }^{1}$, M. M. Savard ${ }^{2}$, C. Bégin ${ }^{2}$, F. Gennaretti ${ }^{4}$, D. Arseneault ${ }^{4}$, J. Marion ${ }^{2}$, A. Nicault ${ }^{3}$, and Y. Bégin ${ }^{1}$ \\ ${ }^{1}$ Institut national de la recherche scientifique-ETE, 490 rue de la Couronne, QC, G1K9A9, Canada \\ ${ }^{2}$ Geological Survey of Canada, Natural Resources Canada, 490 rue de la Couronne, QC, G1K9A9, Canada \\ ${ }^{3}$ Aix-Marseille University, ECCOREV (3098), Europôle Méditerranéen de l'Arbois, BP 80, 13545 \\ Aix-en-Provence cedex 4, France \\ ${ }^{4}$ Université du Québec à Rimouski, 300 allée des Ursulines, Rimouski, G5L3A1, Canada
}

Correspondence to: M. Naulier (maud.naulier@ hotmail.fr)

Received: 18 November 2014 - Published in Clim. Past Discuss.: 20 February 2015

Revised: 5 August 2015 - Accepted: 14 August 2015 - Published: 17 September 2015

\begin{abstract}
Climatic reconstructions for northeastern Canada are scarce such that this area is under-represented in global temperature reconstructions. To fill this lack of knowledge and identify the most important processes influencing climate variability, this study presents the first summer temperature reconstruction for eastern Canada based on a millennial oxygen isotopic series $\left(\delta^{18} \mathrm{O}\right)$ from tree rings. For this purpose, we selected 230 well-preserved subfossil stems from the bottom of a boreal lake and five living trees on the lakeshore. The sampling method permitted an annually resolved $\delta^{18} \mathrm{O}$ series with a replication of five trees per year. The June to August maximal temperature of the last millennium has been reconstructed using the statistical relation between Climatic Research Unit (CRU TS3.1) and $\delta^{18} \mathrm{O}$ data. The resulting millennial series is marked by the welldefined Medieval Climate Anomaly (MCA; AD 1000-1250), the Little Ice Age (AD 1450-1880) and the modern period (AD 1950-2010), and an overall average cooling trend of $-0.6^{\circ} \mathrm{C}$ millennium ${ }^{-1}$. These climatic periods and climatic low-frequency trends are in agreement with the only reconstruction available for northeastern Canada and others from nearby regions (Arctic, Baffin Bay) as well as some remote regions like the Canadian Rockies or Fennoscandia. Our temperature reconstruction indicates that the Medieval Climate Anomaly was characterized by a temperature range similar to the one of the modern period in the study region. However, the temperature increase during the last 3 decades is one of the fastest warming observed over the last millennium
\end{abstract}

$\left(+1.9^{\circ} \mathrm{C}\right.$ between $\left.1970-2000\right)$. An additional key finding of this research is that the coldest episodes mainly coincide with low solar activities and the extremely cold period of the early 19th century has occurred when a solar minimum was in phase with successive intense volcanic eruptions. Our study provides a new perspective unraveling key mechanisms that controlled the past climate shifts in northeastern Canada.

\section{Introduction}

The recently published work of the Intergovernmental Panel on Climate Change (IPCC AR5, 2013; PAGES 2K consortium, 2013) has shown that northeastern Canada is poorly represented among existing millennial temperature reconstructions in the Northern Hemisphere. For this reason, a better knowledge of regional past climate variations registered in natural archives is needed. The use of natural archives such as trees, sediment or pollen has permitted the reconstruction of temperature variability at regional, hemispheric and global scales for the past millennium (Hegerl et al., 2007; Mann et al., 2009; Moberg et al., 2005; PAGES 2k consortium, 2013). Although some studies have documented past climatic conditions in northern Canada (Moore et al., 2001; Thomas and Briner, 2009; Luckman and Wilson, 2005; Edwards et al., 2008; Viau and Gajewski, 2009; Gajewski and Atkinson, 2003), only one annually resolved millennial temperature reconstruction based on tree-ring widths exists for 
eastern Canada (Gennaretti et al., 2014b; summer temperature reconstruction for Eastern Canada, STREC), but none has been based on the isotopic approach. Consequently, obtaining millennial-long, high-resolution temperature reconstructions from additional proxies in northeastern Canada is important to increase our knowledge of the past climate, and better understand the mechanisms of climate change.

Tree-ring isotope series present the advantage that they generally do not need to be detrended; they retain climatic low-frequency variations, and require fewer trees compared to classical dendrological methods (Loader et al., 2013a; Robertson et al., 1997; Young et al., 2010). Moreover, oxygen $\left(\delta^{18} \mathrm{O}\right)$ and carbon $\left(\delta^{13} \mathrm{C}\right)$ series have proven their suitability for reconstructing past summer temperatures (Anchukaitis et al., 2012; Barber et al., 2004; Daux et al., 2011; Luckman and Wilson, 2005; Porter et al., 2013). Whereas $\delta^{13} \mathrm{C}$ series have often been used for long climatic reconstructions, only a few studies have used long $\delta^{18} \mathrm{O}$ series (Edwards et al., 2008; Richter et al., 2008; Treydte et al., 2006; Wang et al., 2013). A previous study has already proven that $\delta^{18} \mathrm{O}$ is the most suitable isotopic proxy for summer temperature reconstruction in our study region (Naulier et al., 2014, 2015).

In northern Canada, most tree species rarely live more than 300 years (Arseneault et al., 2013). In such regions where old trees are missing, isotopic chronologies can be extended by combining living specimens with subfossil trees preserved in lakes (Boettger et al., 2003; Gagen et al., 2012; Mayr et al., 2003; Savard et al., 2012), and cross-dating stems to determine subfossil tree ages (Arseneault et al., 2013). For the purpose of paleoclimate studies, subfossil stems can be easily extracted and collected from large stocks of drowned subfossil logs in lakes and can be associated with specific edaphic contexts as most specimens are not redistributed in lakes (Gennaretti et al., 2014a).

After cross-dating, the development of a robust millennial, isotopic chronology from the combination of living and subfossil stems involves replicating specimens in order to retain the climate variability of the study site (Haupt et al., 2014; Loader et al., 2013a). However, the amount of material available is often a constraint because of the short lifespan of trees, the difficulty to separate single and thin rings and obtaining enough cellulose for isotopic analysis (Loader et al., 2013b; Boettger and Friedrich, 2009). To overcome these problems, different sub-sampling methods have been developed such as tree pooling (McCarroll and Loader, 2004; Dorado Liñán et al., 2011), serial pooling of consecutive tree rings within an individual tree (Boettger and Friedrich, 2009), and the "offset-pool plus join-point method" (Gagen et al., 2012). This last method has permitted constructing a millennial $\delta^{13} \mathrm{C}$ series with annual resolution and high replication, while reducing the sampling efforts and laboratory analyses (Gagen et al., 2012). Moreover, a statistical analysis of this method has confirmed its robustness and possible ap- plication for the production of millennial $\delta^{18} \mathrm{O}$ series (Haupt et al., 2014).

The present study aims to produce a new paleoclimatic data set based on tree-ring $\delta^{18} \mathrm{O}$ series covering the last millennium in northeastern North America. For this purpose, we develop a 1010 -years long $\delta^{18} \mathrm{O}$ series using a combination of living trees and submerged subfossil stems from one site, and reconstruct the summer maximal temperature. We analyze the main characteristics of the climatic series and evaluate its robustness by comparison with other reconstructed temperature series. Finally, we explore the potential impact of natural forcing (solar radiation and volcanic eruptions) on past climatic variability in northeastern Canada.

\section{Materials and methods}

\subsection{Study area}

The study site is located at the center of the Quebec-Labrador peninsula in northeastern Canada (Fig. 1a). This area is part of the Precambrian Canadian Shield, mainly constituted of granitic and gneissic rocks. The landscape is characterized by a low-altitude plateau (400-600 m), with abundant lakes and wetlands. Forests of the area are dominated by black spruce (Picea mariana (Mill.) BSP) trees, developed as pure open lichen woodlands on well-drained sites, and sprucemoss woodlands in depressions. Balsam fir (Abies balsamea (L.) Mill.) and Tamarack (Larix laricina (Du Roi) Koch) also grow in this region. Wildfires are the most important natural disturbances with a rotation period estimated between 250 to 500 years (Boulanger et al., 2012).

The climate is continental and subarctic with short, mild summers and long, cold winters. Environment Canada data (Schefferville station) show that the 1949 to 2010 mean monthly temperature is $-22.9^{\circ} \mathrm{C}$ in January and $13.3{ }^{\circ} \mathrm{C}$ in July with a mean annual temperature of $-3.9^{\circ} \mathrm{C}$. Total annual precipitation averaged $640 \mathrm{~mm}$ with up to $60 \%$ falling in summer (June to September). The mean duration of the frost-free period is 75 days from mid-late June to midSeptember. The lakes are generally frozen from mid-October to early June.

The selected lake (L20; $\left.54^{\circ} 56^{\prime} 31^{\prime \prime} \mathrm{N} ; 71^{\circ} 24^{\prime} 10^{\prime \prime} \mathrm{W}\right)$ is part of the large network of lakes sampled by our group (Arseneault et al., 2013; Gennaretti et al., 2014a and b). Ecological and morphological criteria have been developed to identify lakes that present the best potential for millenniallong climatic reconstructions (well-preserved subfossil trees) and large stocks of subfossil logs. These lakes are typified by an abrupt lake/forest transition, as well as log accumulation in the lower littoral zone away from ice erosion and waves (Arseneault et al., 2013, Gennaretti et al., 2014a, c). Lake L20 has an altitude of $483 \mathrm{~m}$ and an area of 35.1 ha. It is bordered by open spruce-moss with lichen woodlands growing on well-drained podzolic soil and regular slope. The last severe wildfire occurred at about AD 1590 along the 


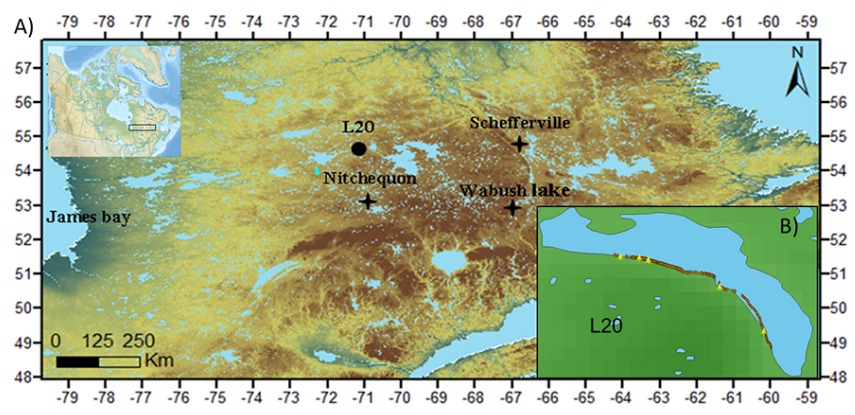

Figure 1. (a) Site location (black circle) and meteorological stations (black stars). (b) Representation of lake L20, also illustrating the sampling location of subfossil stems (brown marks) and living trees (yellow marks).

southern section of the studied shore segment and more than 1200 years ago along the northern section (Gennaretti et al., 2014c).

\subsection{Tree stem selection and sampling strategy}

We recently demonstrated that isotopic series from different heights along lakeshore trees provide similar isotopic trends, and indicated that the combination of lakeshore black spruce trees with subfossil stem segments does not introduce artifacts in long $\delta^{18} \mathrm{O}$ series, thus permitting their combination for climatic reconstruction (Naulier et al., 2014). In the present study, subfossil stems were selected from a large collection of 586 cross-dated specimens from lake L20, also used in the STREC reconstruction (Gennaretti et al.,2014b), based on their excellent degree of preservation (Savard et al., 2012), relatively large ring width $(>0.2 \mathrm{~mm})$ and their life span (Table S1 in the Supplement). The development of a millennial isotopic series requires choosing an appropriate method to preserve both high and low climate frequencies, while limiting analytical efforts. We decided to adapt the "offset-pool plus join-point method" (Gagen et al., 2012) in order to obtain an annual resolution with a replication of five trees for each year.

According to this sampling method, one cohort is made by selecting segments from five contemporaneous trees such that each cohort overlaps the next one over 5 years. In our case, five living trees were selected to construct a modern cohort (CV; AD 1860-2006) and 60 well-preserved subfossil stems from the lake floor were used to produce 12 subfossil cohorts (C0 to C11; AD 997-1956; Fig. 2). Overall, our cohorts cover between 59 and 111-years and the complete suite of cohorts extends from AD 997 to 2006. Additionally, within every cohort, each tree was divided into 5-year blocks which were offset by 1 year among trees (Table S2). As a consequence, the $\delta^{18} \mathrm{O}$ value obtained for a specific year is the mean of the isotopic results from five trees, which represents a triangular centralized 9-year moving average.

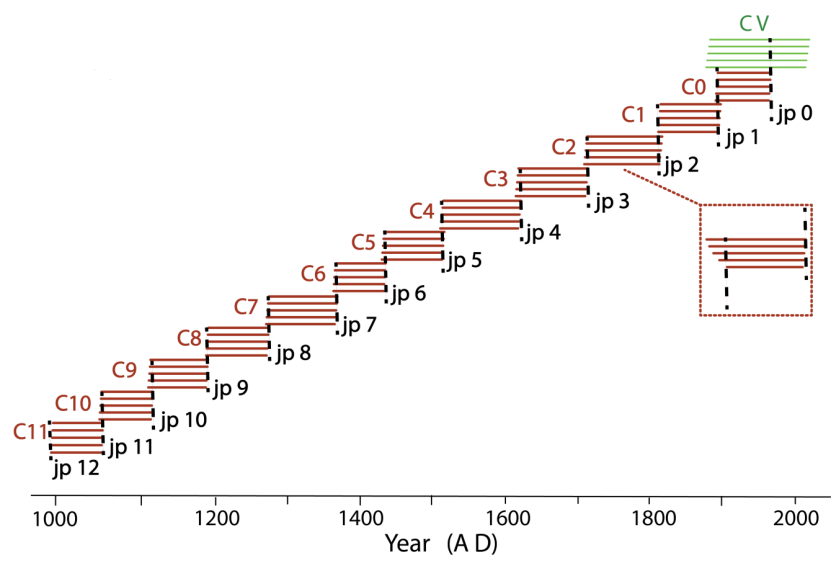

Figure 2. Illustration of the sampling strategy. From year 1000 to 2006, cohorts are represented in red for subfossil stem segments $(\mathrm{C} 0-\mathrm{C} 11)$, and in green for living trees $(\mathrm{CV})$. The join points are in black on the overlapping periods (JP0 to JP12).

\subsection{Laboratory treatment}

We extracted $\alpha$-cellulose sub-samples according to a standard protocol modified for small samples at the Delta-lab of the Geological Survey of Canada (Green, 1963; Savard et al., 2012). The extracted $\alpha$-cellulose was dried at $55^{\circ} \mathrm{C}$ for $12 \mathrm{~h}$ and sub-samples analyzed using peripherals on-line with gassource isotope ratio mass spectrometers (IRMS). All material was analyzed for $\delta^{18} \mathrm{O}$ values with a pyrolysis-CF-IRMS (Delta plus XL). The analytical accuracy of this instrument was $0.2 \% \circ(1 \sigma)$, as established by using international standards (IAEA-SO-6 and IAEA-NBS-127). All $\delta^{18} \mathrm{O}$ measures are reported in permil $(\% o$ ) relative to the Vienna Standard Mean Ocean Water (VSMOW). A total of 2192 analyses were produced, with, in addition, $24 \%$ of all samples retreated and analyzed to determine the external precision (reproducibility) of the complete procedure $(0.2 \%, 1 \sigma)$.

\subsection{Cohort corrections and climatic reconstruction}

When a long isotopic series is produced from trees coming from a random assemblage, joining two successive cohorts may be difficult due to the existence of isotopic offsets between cohorts. An approach to overcome this problem is to use the mean of $\delta^{18} \mathrm{O}$ values coming from several tree segments from the overlap period between two successive cohorts that permit to estimate a correction factor for the offset (Gagen et al., 2012). In the present study, the construction of the millennial $\delta^{18} \mathrm{O}$ series required such an adjustment for some cohorts. We have adopted the "join-point method" proposed by Gagen et al. (2012). A join-point (hereafter JP), corresponds to the mean results of 5-year blocks from several trees overlapping between two cohorts. We have used all available dated trees (between 10 and 24) to produce the required join points (JP 0 to JP 11), and verified several methods to correct for the offsets between cohorts. Hence, every 
cohort has been corrected by adding the linear regression calculated between the $\delta^{18} \mathrm{O}$ values of its two ends.

The integrity of the isotopic signal has been verified elsewhere (Naulier, 2015). The $\delta^{18} \mathrm{O}$ values of lignin and cellulose have been analyzed for three contrasted climatic periods of the millennium (AD. 1141-1164, 1741-1761 and 1886-1909), as detected in previous studies (e.g., Savard et al., 2012). The cellulose isotopic integrity of the subfossil stems has been confirmed by the similarity of the $\Delta$ values between living trees and subfossil stems for the 1886-1909 period. In addition, the departure between the $\delta^{18} \mathrm{O}$ values of lignin and cellulose $\left(\Delta=\delta^{18} \mathrm{O}_{\text {cellulose }}-\delta^{18} \mathrm{O}_{\text {lignin }}\right)$ exhibit no temporal trend.

In previous studies, we have analyzed the relationships between $\delta^{18} \mathrm{O}$ series of five living trees and various climatic parameters (temperature, precipitation, vapor pressure deficit, etc.). We have established that $\delta^{18} \mathrm{O}$ series of black spruce stems sampled at an annual resolution from boreal lakeshore were significantly correlated with June-August (JJA) maximal temperature $\left(T_{\max } ; r=0.54\right)$. We have also determined by statistical analysis (Buishand test, Buishand, 1982) that the summers became warmer after 1975 and that the growing season duration and degree-days have increased importantly during the last decade (2000-2010). Moreover, we have demonstrated that during this decade the growing season started sooner and finished later than before, changing the relationship between JJA maximal temperature and $\delta^{18} \mathrm{O}$ series (divergence). In other words, this JJA $T_{\max }$ and $\delta^{18} \mathrm{O}$ series relation is stable and strong between 1930 and $2000\left(r_{\text {mean }}=0.54 ; 1930-2000\right)$, but not after (AD 20002010; Naulier et al., 2014, 2015). Therefore, in the present study, we excluded the last decade (divergent years) when calibrating the $\delta^{18} \mathrm{O}$ series on temperature data which is assumed to be non-representative of the temperature variation over the last century. The $\delta^{18} \mathrm{O}$ series of subfossil cohorts are filtered on 9 years; we have made the choice to pass a 9-year centered-filter on the JJA maximal temperature CRU TS 3.1 in order to use series all treated in the same way for the reconstruction.

In a first step, a simple linear regression and a linearscaling model were calibrated over the entire 1930-2000 period with climatic data. Climate data from the 1900-1929 period were excluded because no meteorological station was then operating at less than $300 \mathrm{~km}$ from the study site. The climatic series was separated into two equal periods (AD 1930-1970 and 1971-2000; Table 1) in order to test the robustness of the two calibration models, using the non-firstdifferenced reduction of error (RE), the coefficient of error (CE), the raw mean squared error (RMSE) and the coefficient of determination $\left(r^{2}\right)$. The linear regression and the linearscaling calibration procedures resulted in somewhat different temperature reconstructions of similar robustness with similar RE, CE, $r^{2}$ and RMSE coefficients. In both cases, the model residuals satisfy the standard linear regression assumptions of normality, variance and autocorrelation (not shown), but cannot reproduce all attributes of the measured data. We therefore tested the possibility of averaging the two model results, and this option gave the best reproduction of the measured $T_{\max }$. Consequently, we averaged results from the two reconstructions in order to obtain one robust reconstruction (Table 1; Table S3).

Then, i-STREC was compared to the only other regional temperature reconstruction (STREC; Gennaretti et al., 2014), which is built from ring width data from six lakes, including our site, and with reconstructions based on tree rings from another boreal region (Fennoscandia, Helama et al., 2002; Fig. 5). We also compared i-STREC with independent temperature reconstructions based on other natural archives from North America and the Arctic region (Thomas and Briner, 2009; Kobashi et al., 2011; Luckman and Wilson, 2005; Vinther et al., 2009, Fig. 5). Most published reconstructions are based on mean temperatures, except our reconstruction and the one from the Canadian Rockies, which are based on summer maximal temperatures. The influence of climatic forcings was evaluated through the comparison of i-STREC with time series of sulfate emission from volcanic origin (Sigl et al., 2013) and solar radiation series (Bard et al., 2003; Fig. 6). The durations of the solar minima have been determined according to existing estimations of solar radiation (e.g., Bard et al., 2003).

\section{Results and discussion}

\subsection{Development of $\delta^{18} \mathrm{O}$ chronology}

As the purpose of the reconstruction was to identify contrasted periods and important temperature changes over the last millennium, the choice of the sampling method proposed by Boettger and Friedrich (2009) was relevant because it allows for reconstruction of climatic parameters at an annual resolution with a replication of five trees per year. The range of $\delta^{18} \mathrm{O}$ values of trees is between 19.5 and $22.0 \%$, and the largest $\delta^{18} \mathrm{O}$ differences among trees within a junction is obtained for JP5 (3.8\%o; Fig. 3a). This large inter-tree variability can be explained by a combination of causes, including different growing locations along the lakeshore which influence the water supply of trees (Fig. 1b), and inter-tree metabolic variability $(0.5 \%$ in Naulier et al., 2014). Such variability confirms the need to take a large number of trees for a millennial reconstruction in order to capture the site signal (Loader et al., 2013a).

The $\delta^{18} \mathrm{O}$ values at intersections between two successive cohorts and of the JP $\delta^{18} \mathrm{O}$ means are surprisingly matching in most cases (except at the $\mathrm{C} 8 / \mathrm{C} 9$ and $\mathrm{C} 3 / \mathrm{C} 4$ junctions; Fig. 3). These observations suggest that offset correction between cohorts is not always necessary. However, we have determined that a modification of the JP adjustment procedure published by Gagen et al. (2012) would optimize the correction while conserving the isotopic variability and trends over the millennium (Naulier, 2015). Hence, we have used the 
Table 1. Summary of the verification statistics for calibrations using the linear scaling and simple linear regression methods for different periods, and using the measured maximal temperature series.

\begin{tabular}{lrrr}
\hline & $\begin{array}{r}\text { Calibration } \\
(1930-1970)\end{array}$ & $\begin{array}{r}\text { Calibration } \\
(1971-2000)\end{array}$ & $\begin{array}{r}\text { Calibration } \\
(1930-2000)\end{array}$ \\
& $\begin{array}{r}\text { Linear scaling/simple } \\
\text { linear regression }\end{array}$ & $\begin{array}{r}\text { Linear scaling/simple } \\
\text { linear regression }\end{array}$ & $\begin{array}{r}\text { Linear scaling/simple } \\
\text { linear regression }\end{array}$ \\
\hline Average ${ }^{\circ} \mathrm{C} \pm \mathrm{SD}$ & $15.9 \pm 0.3$ & $16.4 \pm 0.4$ & $16.1 \pm 0.4$ \\
$R^{2}$ calibration & $0.27 / 0.43$ & $0.85 / 0.85$ & \\
$R^{2}$ verification & $0.85 / 0.85$ & $0.27 / 0.43$ & \\
$R^{2}$ total period & & & \\
$\mathrm{RMSE}$ verification, ${ }^{\circ} \mathrm{C}$ & $0.14 / 0.33$ & $0.34 / 0.33$ & \\
$\mathrm{RMSE}$ calibration, ${ }^{\circ} \mathrm{C}$ & $0.33 / 0.16$ & $0.15 / 0.14$ & 0.64 \\
$\mathrm{RMSE}$ total period, ${ }^{\circ} \mathrm{C}$ & $0.94 / 0.19$ & $0.64 / 0.07$ & $0.57 / 0.64$ \\
$\mathrm{RE}$ & $0.84 / 0.05$ & $-0.02 / 0.21$ & $0.57 / 0.64$ \\
$\mathrm{CE}$ & & & \\
\hline
\end{tabular}

SD is the standard deviation, $r^{2}$ is the coefficient of determination $\left(R^{2}\right)$, RMSE the raw mean squared error, RE the reduction of error and CE the coefficient of error.

mean of $\delta^{18} \mathrm{O}$ values of JP from overlapping cohorts to calculate the required adjustment, this mean being considered as "the adjustment value". Correcting cohort $\delta^{18} \mathrm{O}$ series with this method increases the number of trees considered (20 to 33 trees instead of 10 to 23 trees if only JP are used). After correction, the mean of the millennial $\delta^{18} \mathrm{O}$ series is $20.8 \%$ o. The strong correlation between the $\delta^{18} \mathrm{O}$ series of living trees and subfossil stems $\left(r^{2}=0.70\right)$ over their overlapping period (1860-1956) confirms the isotopic integrity of the subfossil stems, and ensures that the climatic reconstruction can be performed over the rest of the millennial $\delta^{18} \mathrm{O}$ series.

Although the cohort sampling method presents many positive points, it is important to highlight some of its flaws. Indeed, the sampling strategy produces a $\delta^{18} \mathrm{O}$ series smoothed with a centered 9-year filter. This smoothing leads in some cases to series requiring more precaution than non-smoothed series before they can be interpreted or used. For instance, the calibration of our smoothed $\delta^{18} \mathrm{O}$ series required a centered 9 -year filtering of the climatic series. Consequently, correlations between isotopic and climatic series are improved by smoothing due to the sampling method. Nevertheless, these correlations represent solid and real links, and do not create artifacts (see also Sect. 3.2.1, and Naulier et al., 2014).

\subsection{Model validation and millennial climatic reconstruction}

\subsubsection{Model validation}

We have compared two methods of sampling and production of the ring series from living trees prior to calibration: (1) separation at an annual resolution without pooling (e.g., Haupt et al., 2014); and (2) sampling with the cohort approach. We have found that the second was best suited because it slightly improved the correlation between $\delta^{18} \mathrm{O}$ series and maximal temperatures $\left(r^{2}=0.64\right.$ vs. 0.54 with an- nual resolution), and it allows using $\delta^{18} \mathrm{O}$ series compatible with the one used for the millennial subfossil series (9-year moving average). Consequently, the $\delta^{18} \mathrm{O}$ series of the livingtree cohort (CV) was used to calibrate the model and to provide a robust reconstruction as it show a strong correlation with the new CRU series $\left(r^{2}=0.64\right)$ for the entire calibration period (1930-2000), which confirmed that the reconstruction of past temperature with the average $\delta^{18} \mathrm{O}$ series is suitable (Fig. 4a). The RMSE is 0.26, with an RE and a CE of 0.60. However, it appears that the calibration and verification coefficients are significantly changing depending on the period selected for the statistical analysis. This observation implies that the correlation between $T_{\max }$ and $\delta^{18} \mathrm{O}$ series is not stable over the last century even if the correlation stays significant (Naulier et al., 2015).

These statistical results confirm that the summer temperature reconstructed based on $\delta^{18} \mathrm{O}$ values (i-STREC) are representative of the natural variability that existed in northeastern Canada.

\subsubsection{Millennial temperature trends in northeastern Canada}

The i-STREC shows a $0.6^{\circ} \mathrm{C}$ decrease of maximum summer temperature over the past millennium (Fig. 4b), whereas a millennial $0.2^{\circ} \mathrm{C}$ cooling is roughly estimated for the mean temperature of the Northern Hemisphere (PAGES 2k consortium, 2013). However, our local temperature decrease is in the same order of magnitude as the decrease of summermonths mean temperature reconstructed using pollen in the North American tundra (Viau et al., 2012), and in northern regions of high latitudes (sediment, tree-ring widths, ice core in Kaufman et al., 2009 and tree-ring widths in Esper et al., 2012). This temperature decline over the last millennium is 

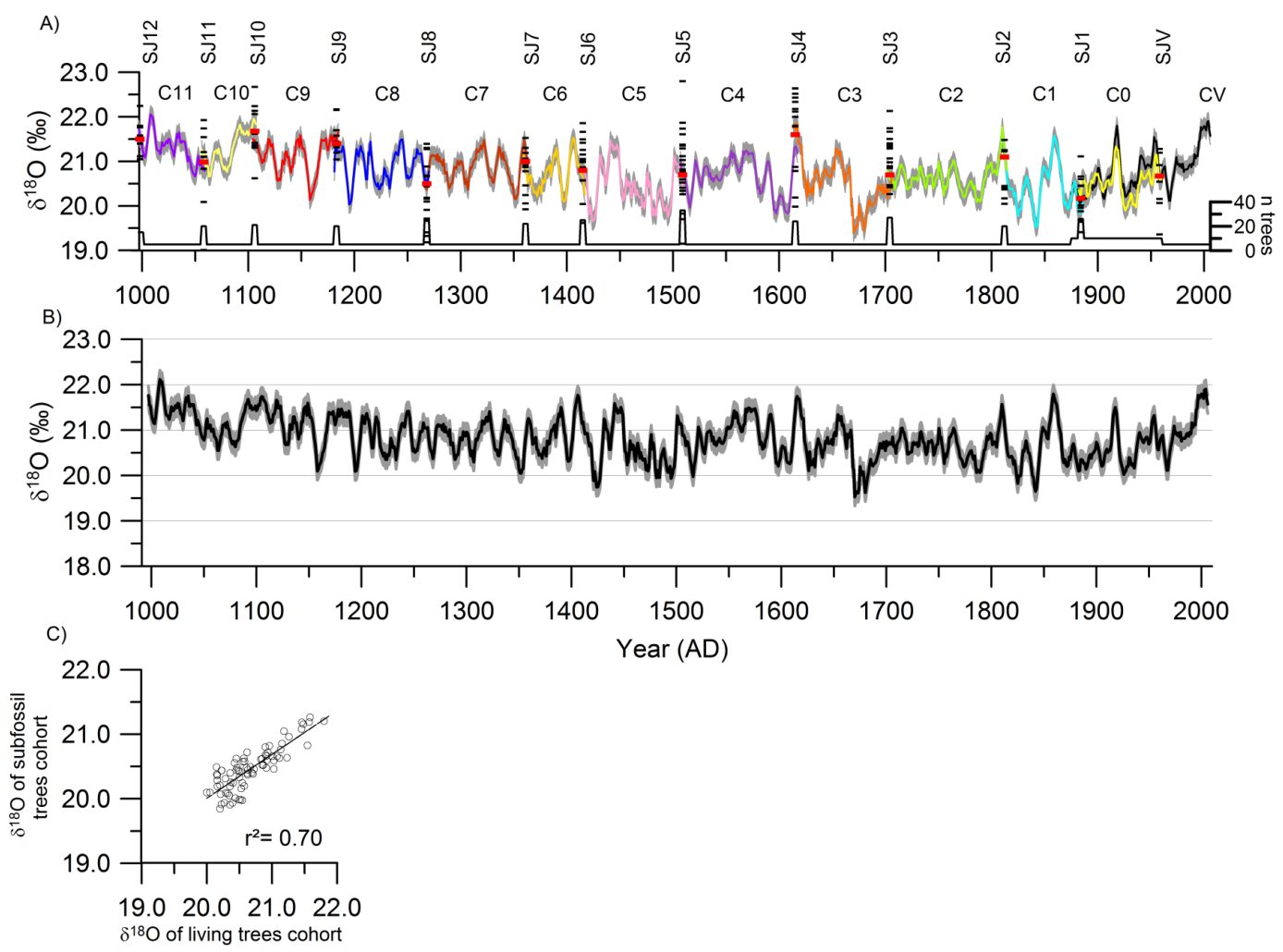

Figure 3. (a) Millennial raw $\delta^{18} \mathrm{O}$ series (1000-2010) with subfossil segment cohorts (cohorts $\mathrm{C} 0$ to $\mathrm{C} 11$; illustrated with different colors), living tree cohort (CV; dark pink curve), and join points (blue dash), the adjustment means (black dash) and the number of tree segments used per year (straight black line). The gray envelop represents the analytical error $(0.2 \%$ ). The legend shows the correspondence between the colors curves and cohorts. (b) Millennial $\delta^{18} \mathrm{O}$ series adjusted (black line) with standard deviation (gray lines). (c) Comparison between $\delta^{18} \mathrm{O}$ values of living trees and subfossil stem segments over the common time interval (1860-1956).

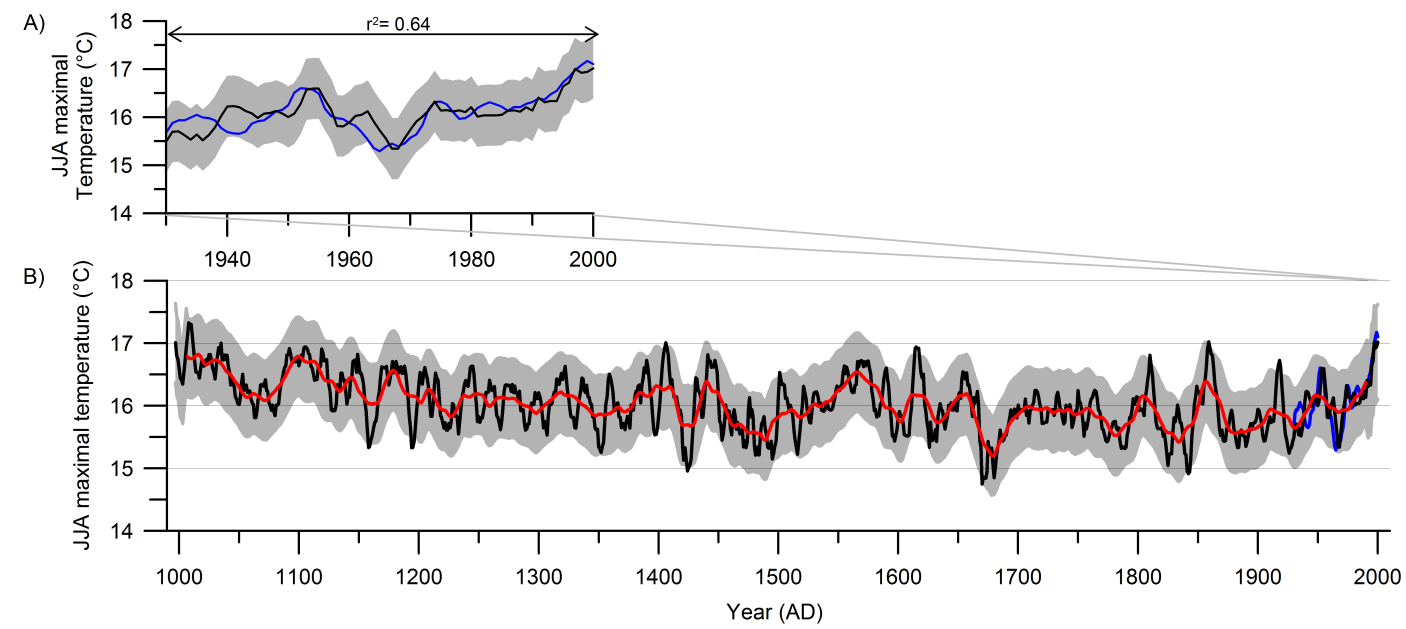

Figure 4. (a) Comparison between reconstructed (i-STREC, black line) and observed (blue line) JJA maximal temperature and mean square values on the entire period of calibration. (b) i-STREC (black line) with 21-year moving average (red line) and observed JJA maximal temperature series from CRU TS3.1 (blue line). In both cases, the dark gray shading represents uncertainty with \pm 1 RMSE calculated on the 21-year filter values. 
generally attributed to orbital forcing (PAGES 2k consortium, 2013).

The reconstruction suggests that the maximum summer temperature has varied from a maximum of $17.3^{\circ} \mathrm{C}$ around $\mathrm{AD} 1008-1010$ to a minimum of $14.8^{\circ} \mathrm{C}$ around AD 1670-1674. The 20th century was generally cold (mean of $16^{\circ} \mathrm{C}$ ) with an abrupt warming trend during the last 3 decades $\left(+0.2^{\circ} \mathrm{C} 10 \mathrm{yr}^{-1}\right.$ between $\mathrm{AD} 1900-1980$ and $+0.8^{\circ} \mathrm{C}_{\text {decade }}{ }^{-1}$ between AD 1980-2010; CRU TS 3.1 data; Fig. 4a). Furthermore, two major climatic episodes were also revealed by i-STREC: a warm period during the 11 th and 12th centuries (mean of $16.5^{\circ} \mathrm{C}$ between 1000 and 1250) and a cold period from the early 15 th to the end of the 19th century (mean of $15.8^{\circ} \mathrm{C}$ between 1450 and 1880; Fig. $4 \mathrm{~b}$ ). These periods are in agreement with the general knowledge of the temperature trends observed globally for the last millennium and correspond to the Medieval Climate Anomaly (MCA) and the LIA, respectively (IPCC, 2013; PAGES $2 \mathrm{k}$ consortium, 2013). Based on i-STREC data, we associate these two climatic episodes to the $\sim$ AD 1000 1250 and $\sim$ AD 1450-1880 time periods, respectively.

\subsubsection{Evidence of contrasted climatic periods}

The high summer temperatures of the 11th century (AD $\sim 1000-1250$; Fig. 4b) coincide with peaks previously observed in our study area based on tree-ring width (Gennaretti et al., 2014b; STREC), as well as in Greenland ice cores (Kobashi et al., 2011; Vinther et al., 2009, 2010), tree-ring series from the Canadian Rockies (Luckman and Wilson, 2005) and Fennoscandia (Helama et al., 2002; Fig. 5), and large-scale reconstructions (Mann et al., 2009; Ljungqvist et al., 2012; Kaufman et al., 2009; Trouet et al., 2013). Several hypotheses on the forcing of this warm anomaly have been proposed, including a prolonged tendency towards a positivephase of the North Atlantic Oscillation (NAO; Trouet et al., 2009, 2012) or a synchronicity between La Niña phase and a warm phase in the Atlantic Multidecadal Oscillation (AMO; Feng et al., 2011; Mann et al., 2009). In northeastern Canada, the NAO has an important impact on winter temperatures but not for summer (Hurrell et al., 2003). In contrast, the AMO influences spring and summer temperatures (Fortin and Lamoureux, 2009) and is partly responsible for the recent sea surface temperature warming of northeastern Canada (Ding et al., 2014). However, the state of the AMO at the beginning of the millennium and its potential influence on climate during the MCA are unknown. Recently, Sicre et al. (2014) demonstrated that during the MCA, the Northern Annular Mode (NAM) was effective concomitantly with a strong iceloaded Labrador Current (LC). This combination could be responsible for a decrease of fresh air from the Arctic to eastern Canada, and consequently, for an increased temperature along the continent.

Following the MCA, i-STREC emphasizes a cold period between $\sim \mathrm{AD} 1450$ and 1880, which can be attributed to the

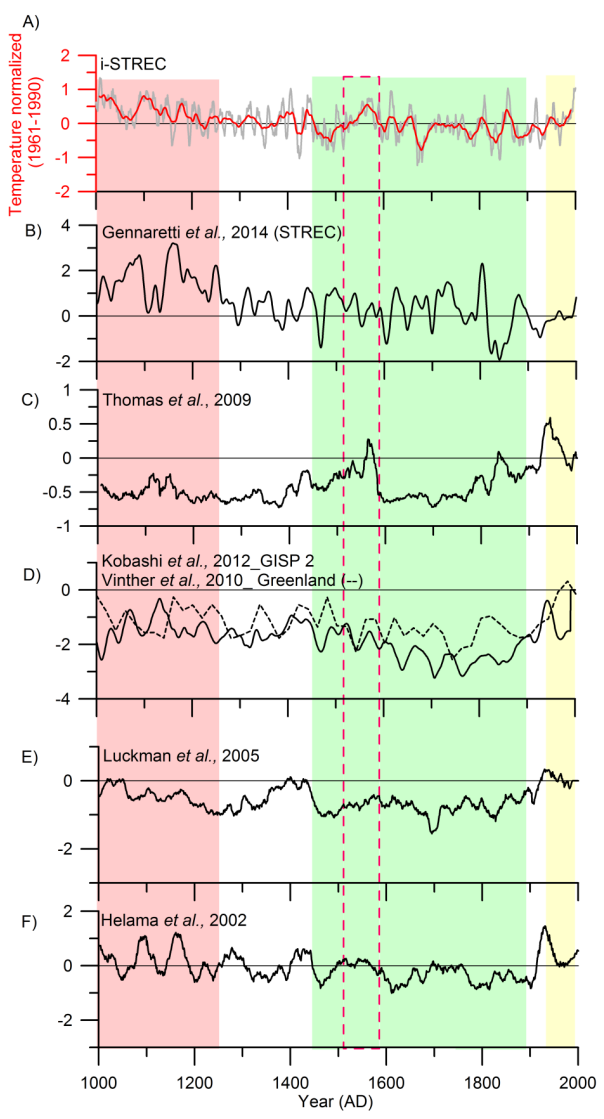

Figure 5. Comparison between i-STREC and other temperature reconstructions (data obtained from NOAA). (a) i-STREC from northeastern Canada. (b) STREC from tree-ring width, in the same region. (c) July-September temperature from varved sediments, Baffin Island, Arctic Canada (Thomas and Brinner, 2008). (d) Annual surface temperature from GISP 2 ice core, in Greenland. (e) May-August maximum temperature from maximum latewood density and tree-ring width, Canadian Rockies. (f) July temperature from tree-ring width, northern Finland. Shading based on i-STREC is shown to ease comparison with the other reconstructions compiled: warmer (pink, colder (green) and modern periods (yellow). All reconstructions have been smoothed with a 21-year filter and normalized (1960-1991).

Little Ice Age (LIA; Fig. 4b). It is worth noting that a short warming phase occurred between 1510 and 1590 (Fig. 4b). Such warm phase also occurred at the eastern Canadian treeline and included the expansion of upright tree growth forms in lichen-spruce woodland (Payette et al., 1989). Overall, the LIA is recorded in several Northern Hemisphere temperature reconstructions based on various proxies, even if its length varies among regions (PAGES 2k consortium, 2013). At the hemispheric scale, the LIA is a well-documented cool period (Moberg et al., 2005; Mann et al., 2009; Hegerl et al., 2007), and several causes may have concurred to trigger its occurrence, including a succession of strong volcanic eruptions (Crowley, 2000; Miller et al., 2012, Gennaretti et al., 
2014b), millennial orbital cooling (Kaufman et al., 2009; Esper et al., 2012), and low solar radiation (Bard et al., 1997).

It is without surprise that the MCA was warmer than the LIA $\left(+0.4 \pm 0.3^{\circ} \mathrm{C}\right)$ in the L20 area. We have furthermore compared maximal temperature of the MCA with the modern warming, following the approach used in the IPCC report (Masson-Delmotte et al., 2013). The running 50-years averages between 1000 and 1100 were higher $\left(+0.2 \pm 0.1^{\circ} \mathrm{C}\right)$ than the measured temperature of the last 50 years (19592009). It is worth noting that when considering 30-years running averages, the 1979-2009 period appears to be the warmest (average of $+0.6^{\circ} \mathrm{C} \pm 0.4$ ) over the last millennium. Considering these results, one can infer that the MCA and recent warming show similar average maximal temperature in the study area.

These results contrast somewhat with Northern Hemisphere temperature reconstructions that have determined that the mean annual temperature of the modern period was the warmest in northern Canada (Mann et al., 2009; Ljungqvist et al., 2012). Indeed, the data available for these hemispheric reconstructions in the last IPCC report are scarce for northeastern Canada (Viau et al., 2012). Clearly, the i-STREC results indicate that the MCA in northeastern Canada has been as warm as the modern period of the last millennium (Fig. 5). The similarities between MCA and the modern period were expected considering that the MCA has been widely studied for its similarities with the modern warming period. Nevertheless, the causes that triggered these similar climatic periods are likely different (i.e., Landrum et al., 2013; Way and Viau, 2014). Indeed, if the MCA is solely controlled by natural processes, it seems that the warming during the modern period results from a combination of natural and anthropogenic causes (i.e., Mann et al., 2009; Viau et al., 2015). By using empirical statistical modeling and global climate models for the 1881-2011 period in Labrador, Way and Viau (2014) have shown that up to $65 \%$ of the variance in annual air temperature was explained when also including anthropogenic forcing in the model. Even if summer temperature has increased at a lower rate compared to annual air temperature in Labrador, the observed warming $\left(+1.9^{\circ} \mathrm{C}\right)$ between 1970 and 2000 in the region of L20 is one of the fastest over the last millennium. In the next decades, if warming continues at this rate, temperature will reach a new record for the last millennium.

\subsubsection{Climatic forcings of the last millennium}

Contrary to previous studies, our isotopic series do not emphasize an abrupt LIA onset in response to volcanic forcing such as the AD 1257 Samalas event (Lavigne et al., 2013; Fig. 6). Instead, our data suggest that solar radiation was the most influential forcing on $T_{\max }$ changes in the studied region. Indeed, the most important cooling phases of iSTREC occurred during periods of low solar activity like the Oort (AD 1040-1080), Dalton (AD 1800-1850), Maun- der (AD 1600-1650) and Spörer (AD 1410-1480) minima (Fig. 6). A simple re-sampling method involving 1000 iterations of re-sampling (bootstrapped) has demonstrated that the low temperature periods were always associated to low solar radiation periods $(p<0.05)$. Proposing that solar radiation represents an important control on temperature in northeastern Canada is in agreement with the hypothesis that the solar forcing was important during the last millennium (AD 1000 to $\sim 1900$ ), except during the modern period (Breitenmoser et al., 2012; Keller, 2004), implying that recent anthropogenic impact is the main control at that time. However, even i-STREC is not significantly influenced by volcanism, as determined by superimposed epoch analysis (results not shown), the possibility that successive strong volcanic eruptions combined with solar minima could have contributed to the important LIA cooling in Northeastern Canada cannot be discarded. Strong eruptions and solar minima coincide during the Maunder minimum with the Kuwae eruption, and the Dalton minimum with the unknown (1809), Tambora (1815) and Cosiguïna (1835) eruptions. The role of coinciding natural forcings is also invoked in other paleoclimatic studies that have compared Northern Hemisphere reconstructions with solar radiation series (e.g., Bard et al., 2006; Breitenmoser et al., 2012; Crowley, 2000; Lean et al., 1995; Shindell et al., 2003). These studies have shown that temperature changes were largely due to solar forcing alone during the first part of the last millennium, and to volcanic and solar forcings (i.e, Breitenmoser et al., 2012), or to volcanic eruptions (i.e., Crowley et al., 2000; Keller et al., 2004) during the end of the LIA (after 1600). In addition, Tingley et al. (2014) have demonstrated, by analyzing the ring density in trees growing at high latitude, that the trees recorded not only volcanic eruptions but also variations in light intensity. This finding indicates that both isotopes and density of trees can record changes in solar radiations.

The other temperature reconstruction produced for the studied region (STREC) contains a stronger volcanic signal than i-STREC (Gennaretti et al., 2014b). Considering that the two reconstructions are statistically robust, we can assume that they both reflect real trends. In addition, calibrating STREC using the same approach than for i-STREC (i.e., calibration on maximum temperature over the 1930-2000 time period) indicates that methods cannot account for the main differences between the two reconstructions. Consequently, differences in thermal trends between i-STREC and STREC must be caused by their respective sensitivity to climatic triggers and control mechanisms, ring width and $\delta^{18} \mathrm{O}$ values. The first important point to bear in mind is that temperature is the main control on changes in ring widths and $\delta^{18} \mathrm{O}$ values, but not the only one. Consequently, other climatic parameters (i.e., precipitations, vapor pressure deficit) have also generated short and medium variations on the two series, creating an important "climatic noise" at high and medium frequencies, possibly explaining the differences between the reconstructions (Naulier et al., 2014). However, the ring width and 


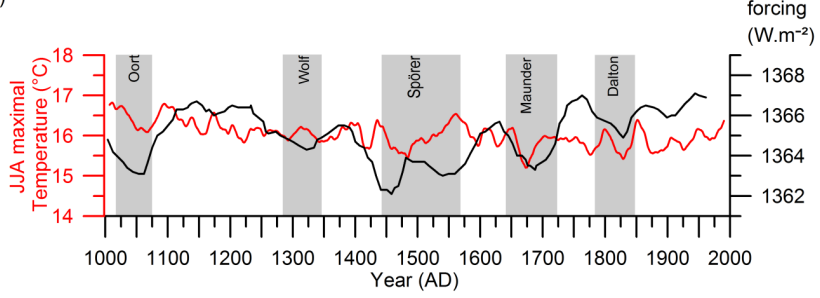

B)

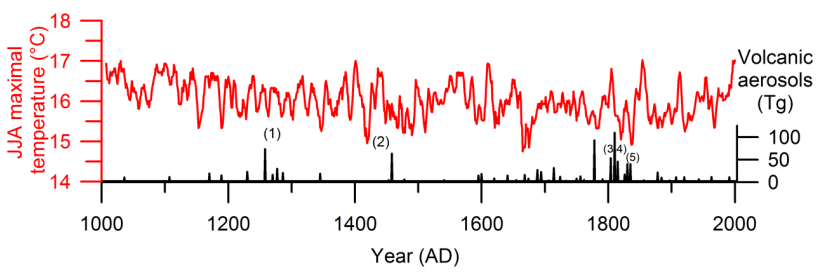

Figure 6. Volcanic and solar forcings. (a) I-STREC (reconstructed summer temperature, 21-years smoothed; red line), compared with the well-known solar minima (gray bands) and the solar forcing series (black line; Bard et al., 2003). (b) I-STREC reconstructed summer temperature (red line) compared with the volcanic aerosols sulfates (Sigl et al., 2013). The major eruptions are marked: (1) $1257 / 1258=$ Samalas, (2) $1456=$ Kuwae, (3) $1783=$ Laki, (4) $1809=$ unknown and $1815=$ Tambora and (5) $1835=$ Cosigüina).

$\delta^{18} \mathrm{O}$ series used to generate STREC and i-STREC display similar long-term climatic trends. This last point is quite important, considering that our main purpose was to identify long climatic tendencies over the last millennium in northeastern Canada.

The second important aspect to consider is that the temperature-linked processes responsible for the variations of ring widths and $\delta^{18} \mathrm{O}$ values slightly differ. In the studied region, rings widths are directly influenced by photosynthetic rates, which generally increase with ambient temperatures. In addition, volcanic aerosols blocking light after a major volcanic eruption may also reduce ring growth concomitantly to reduced temperature, explaining the strong influence of major volcanic events on ring width. In contrast, one of the main controls on the final tree-ring $\delta^{18} \mathrm{O}$ values is the temperature prevailing regionally during cloud mass distillation, as registered in the raindrop signal and transferred to the source water in soils, then through the root system, to the tree. Moreover, the temperature effects on fractionation during distillation and precipitation (Rayleigh process) are not limited to a temperature range, and may record temperature lows modulated by solar minimums. When strong volcanic events are combined with minimal solar radiations, the strong influence on regional temperature is therefore detected by $\delta^{18} \mathrm{O}$ values of rain drops. These key differences in mechanisms controlling temperature recorded in ring widths and $\delta^{18} \mathrm{O}$ values imply that the two proxies may emphasize forcings in a complementary way.

As a summary, it appears that ring widths or $\delta^{18} \mathrm{O}$ series have strengths and weaknesses as proxy of past climatic con- ditions. However, the climatic data that can be extracted from the two series can generate complementary information, permitting to highlight several climatic forcings and identify the main regional control on past, present and future temperatures. Nevertheless, there is still a need for further understanding the differences between processes influencing isotopic assimilation and ring-width growth. Such information would be useful for future climatic reconstruction using a multi-indicator approach.

\section{Conclusions}

1. The cohort sampling method allows reconstructing climatic variability of medium and low frequencies by using fewer samples than other sampling methods, with a high temporal resolution and analytical replication. Our adjustment of the method of joining cohorts, the JP-adjustment method, permits the preservation of $\delta^{18} \mathrm{O}$ variability between segments of trees without biasing the millennial $\delta^{18} \mathrm{O}$ series.

2. The combination of two statistical models (linear scaling and simple linear regression) has permitted an adequate reproduction of the measured regional temperature, and allowed reconstructing maximum temperature over the last millennium.

3. i-STREC is complementary to the only other reconstruction in the study region (STREC, based on tree-ring width). These two reconstructions should be combined within a multi-parameter approach to increase the proportions of variance explained.

4. i-STREC suggests that the main climatic forcing at play during the last millennium in the studied region was solar activity, but we remain cautious because we base this hypothesis solely on an apparent correlation between reconstructed $T_{\max }$ and the curve for solar radiations. Clearly, coldest episodes in the L20 area coincide with low solar radiation (Oort, Spörer, Maunder and Dalton), with the exception of an episode in the 19th century, during which low solar radiations (Dalton minima) were combined with two successive and strong volcanic eruptions (unknown 1809 and Tambora 1815 eruptions).

5. Overall, i-STREC shows that the Medieval Climate Anomaly (997-1250) was characterized by a temperature range similar to the one of the modern period in the study region. However, the sudden and rapid temperature increase during the last 3 decades is one of the fastest over the last millennium $\left(+1.9^{\circ} \mathrm{C}\right.$ between 1970 and 2000) and if this rapid warming rate persists, the future climate in northeastern Canada may become an issue of concern. 


\section{The Supplement related to this article is available online at doi:10.5194/cp-11-1153-2015-supplement.}

Acknowledgements. The authors would like to thank Anna Smirnoff, Marie-Christine Simard and Marc Luzincourt for their technical support during sample treatment and analyses at the Delta-Lab of the Geological Survey of Canada. We are grateful to Julia Autin, Pierre-Paul Dion and Yves Bouthillier for the sampling of lakeshore trees and subfossil stems. We also would like to thank Steve Wolfe who made constructive comments during a pre-submission review of this article. This research was supported financially by the NSERC-OURANOS Collaborative Research and Development grant (ARCHIVES project of INRS-ETE), and the Environmental Geoscience Program of the Geological Survey of Canada (ESS contribution no. 20140213).

Edited by: V. Masson-Delmotte

\section{References}

Anchukaitis, K. J., D’Arrigo, R. D., Andreu-Hayles, L., Frank, D., Verstege, A., Curtis, A., Buckley, B. M., Jacoby, G. C., and Cook, E. R.: Tree-ring reconstructed summer temperatures from northwestern North America during the last nine centuries, J. Climate, 3001-3012, doi:10.1175/jcli-d-11-00139.1, 2012.

Arseneault, D., Dy, B., Gennaretti, F., Autin, J., and Bégin, Y.: Developing millennial tree ring chronologies in the fire-prone North American boreal forest, J. Quat. Sci., 28, 283-292, doi:10.1002/jqs.2612, 2013.

Barber, V. A., Juday, G. P., Finney, B. P., and Wilmking, M.: Reconstruction of summer temperatures in interior Alaska from treering proxies: evidence for changing synoptic climate regimes, Clim. Change, 63, 91-120, 2004.

Bard, E., Raisbeck, G. M., Yiou, F., and Jouzel, J.: Solar modulation of cosmogenic nuclide production over the last millennium: comparison between ${ }^{1} 4 \mathrm{C}_{1} 0$ Be records, Earth Planet. Sci. Lett., 150, 453-462, 1997.

Bard, E., Raisbeck, G., Yiou, F., and Jouzel, J.: Reconstructed Solar Irradiance Data. IGBP PAGES/World Data Center for Paleoclimatology Data Contribution Series \#2003-006, NOAA/NGDC Paleoclimatology Program, Boulder CO, USA, 2003.

Boettger, T. and Friedrich, M.: A new serial pooling method of shifted tree ring blocks to construct millennia long tree ring isotope chronologies with annual resolution, Isot. Environ. Health Stud., 45, 68-80, doi:10.1080/10256010802522218, 2009.

Boettger, T., Friedrich, M., Hiller, A., and Kremenetski, K.: Mid-Holocene warming in the northwest Kola Peninsula, Russia: northern pine-limit movement and stable isotope evidence, Holocene, 13, 403-410, doi:10.1191/0959683603hl633rp, 2003.

Boulanger, Y., Gauthier, S., Burton, P. J., and Vaillancourt, M.-A.: An alternative fire regime zonation for Canada, Int. J. Wild. Fire, 21, 1052-1064, doi:10.1071/WF11073, 2012.

Breitenmoser, P., Beer, J., Broennimann, S., Frank, D., Steinhilber, F., and Wanner, H.: Solar and volcanic fingerprints in tree-ring chronologies over the past 2000years, Palaeogeogr. Palaeoecol., $313,127-139,2012$.
Buishand, T. A. Some methods for testing the homogeneity of rainfall data, J. Hydrol., 58, 11-27, 1982.

Crowley, T. J.: Causes of climate change over the past 1000 years, Science, 289, 270-277, 2000.

Daux, V., Edouard, J.-L., Masson-Delmotte, V., Stievenard, M., Hoffmann, G., Pierre, M., Mestre, O., Danis, P., and Guibal, F. Can climate variations be inferred from tree-ring parameters and stable isotopes from Larix decidua? Juvenile effects, budmoth outbreaks, and divergence issue, Earth Planet. Sci. Lett., 309, 221-233, 2011a.

Daux, V., Edouard, J. L., Masson-Delmotte, V., Stievenard, M., Hoffmann, G., Pierre, M., Mestre, O., Danis, P. A., and Guibal, F. Can climate variations be inferred from tree-ring parameters and stable isotopes from Larix decidua? Juvenile effects, budmoth outbreaks, and divergence issue, Earth Planet. Sci. Lett., 309, 221-233, 2011b.

Ding, Q., Wallace, J. M., Battisti, D. S., Steig, E. J., Gallant, A. J., Kim, H.-J., and Geng, L.: Tropical forcing of the recent rapid Arctic warming in north-eastern Canada and Greenland, Nature, 509, 209-212, 2014.

Dorado Liñán, I., Gutiérrez, E., Helle, G., Heinrich, I., AndreuHayles, L., Planells, O., Leuenberger, M., Bürger, C., and Schleser, G.: Pooled versus separate measurements of treering stable isotopes, Sci. Total Environ., 409, 2244-2251, doi:10.1016/j.scitotenv.2011.02.010, 2011.

Edwards, T. W., Birks, S. J., Luckman, B. H., and MacDonald, G. M.: Climatic and hydrologic variability during the past millennium in the eastern Rocky Mountains and northern Great Plains of western Canada, Quaternary Res., 70, 188-197, 2008.

Esper, J., Frank, D. C., Timonen, M., Zorita, E., Wilson, R. J., Luterbacher, J., Holzkämper, S., Fischer, N., Wagner, S., and Nievergelt, D.: Orbital forcing of tree-ring data, Nature Climate Change, 2, 862-866, 2012.

Feng, S., Hu, Q. and Oglesby, R. J.: Influence of Atlantic sea surface temperatures on persistent drought in North America, Clim. Dynam., 37, 569-586, 2011.

Fortin, D. and Lamoureux, S. F.: Multidecadal hydroclimatic variability in north-eastern North America since 1550 AD, Clim. Dynam., 33, 427-432, 2009.

Gagen, M., McCarroll, D., Jalkanen, R., Loader, N. J., Robertson, I., and Young, G. H. F.: A rapid method for the production of robust millennial length stable isotope tree ring series for climate reconstruction, Global Planet. Change, 82-83, 96-103, doi:10.1016/j.gloplacha.2011.11.006, 2012.

Gajewski, K. and Atkinson, D.: Climatic change in northern Canada, Environ. Rev., 11, 69-102, 2003.

Gennaretti, F., Arseneault, D., and Bégin, Y.: Millennial stocks and fluxes of large woody debris in lakes of the North American taiga, J. Ecol., 102, 367-380, 2014a.

Gennaretti, F., Arseneault, D., Nicault, A., Perreault, L., and Bégin, Y.: Volcano-induced regime shifts in millennial tree-ring chronologies from North-eastern North America, P. Natl. Acad. Sci. USA, 111, 10077-10082, 2014b.

Gennaretti, F., Arseneault D., and Bégin, Y. : Millennial disturbance-driven forest stand dynamics in the Eastern Canadian taiga reconstructed from subfossil logs, J. Ecol., 102, 1612 1622, doi:10.1111/1365-2745.12315, 2014c.

Green, J. W.: Wood cellulose, Methods in Carbohydrate Chemistry III, 9-21, 1963. 
Haupt, M., Friedrich, M., Shishov, V. V., and Boettger, T.: The construction of oxygen isotope chronologies from tree-ring series sampled at different temporal resolution and its use as climate proxies: statistical aspects, Clim. Change, 122, 201-215, 2014.

Hegerl, G. C., Crowley, T. J., Allen, M., Hyde, W. T., Pollack, H. N., Smerdon, J., and Zorita, E.: Detection of human influence on a new, validated 1500-year temperature reconstruction, J. Climate, 20, 650-666, 2007.

Helama, S., Lindholm, M., Timonen, M., J., M., and Eronen, M.: The supra-long Scots pine tree-ring record for Finnish Lapland: Part 2, interannual to centennial variability in summer temperatures for 7500 years, Holocene, 12, 681-687, 2002.

Hurrell, J. W., Kushnir, Y., Ottersen, G., and Visbeck, M.: The North Atlantic Oscillation: climatic significance and environmental impact, Geophysical Monograph Series, 134, American Geophysical Union, Washington, DC., 2003.

IPCC: Climatic change 2013: The physical Science Basis., Contribution of working group 1 to the fifth assessment report of the intergovernmental panel on climate change, 1535 pp., 2013.

Kaufman, D. S., Schneider, D. P., McKay, N. P., Ammann, C. M., Bradley, R. S., Briffa, K. R., Miller, G. H., Otto-Bliesner, B. L., Overpeck, J. T., and Vinther, B. M.: Recent warming reverses long-term Arctic cooling, Science, 325, 1236-1239, 2009.

Keller, C. F.: 1000 Years of climate change, Adv. Space Res., 34, 315-322, 2004.

Kobashi, T., Kawamura, K., Severinghaus, J. P., Barnola, J. M., Nakaegawa, T., Vinther, B. M., Johnsen, S. J., and Box, J. E.: High variability of Greenland surface temperature over the past 4000 years estimated from trapped air in an ice core, Geophys. Res. Lett., 38, doi:10.1029/2011GL049444, 2011.

Landrum, L., Otto-Bliesner, B. L., Wahl, E. R., Conley, A., Lawrence, P. J., Rosenbloom, N., and Teng, H.: Last Millennium Climate and Its Variability in CCSM4, J. Climate, 26, 10851111, 2013.

Lavigne, F., Degeai, J.-P., Komorowski, J.-C., Guillet, S., Robert, V., Lahitte, P., Oppenheimer, C., Stoffel, M., Vidal, C. M., and Pratomo, I.: Source of the great AD 1257 mystery eruption unveiled, Samalas volcano, Rinjani Volcanic Complex, Indonesia, P. Natl. Acad. Sci. USA, 110, 16742-16747, 2013.

Lean, J., Beer, J., and Bradley, R.: Reconstruction of solar irradiance since 1610: Implications for climate change, Geophys. Res. Lett., 22, 3195-3198, 1995.

Ljungqvist, F. C., Krusic, P. J., Brattström, G., and Sundqvist, H. S.: Northern Hemisphere temperature patterns in the last 12 centuries, Clim. Past, 8, 227-249, doi:10.5194/cp-8-227-2012, 2012.

Loader, N. J., Young, G. H., McCarroll, D., and Wilson, R. J.: Quantifying uncertainty in isotope dendroclimatology, Holocene, 23, 1221-1226, 2013a.

Loader, N. J., Young, G. H. F., Grudd, H., and McCarroll, D.: Stable carbon isotopes from Torneträsk, northern Sweden provide a millennial length reconstruction of summer sunshine and its relationship to Arctic circulation, Quat. Sci. Rev., 62, 97-113, doi:10.1016/j.quascirev.2012.11.014, 2013b.

Luckman, B. H. and Wilson, R. J. S.: Canadian Rockies Summer Temperature Reconstruction. IGBP PAGES/World Data Center for Paleoclimatology. Data Contribution Series \# 2006-011, NOAA/NCDC Paleoclimatology Program, Boulder CO, USA, 2006.
Mann, M. E., Zhang, Z., Rutherford, S., Bradley, R. S., Hughes, M. K., Shindell, D., Ammann, C., Faluvegi, G., and Ni, F.: Global signatures and dynamical origins of the Little Ice Age and Medieval Climate Anomaly, Science, 326, 1256-1260, 2009.

Masson-Delmotte, V., Schulz, M., Abe-Ouchi, A., Beer, J., Ganopolski, A., González Rouco J.F., Jansen, E., Lambeck, K., Luterbacher, J., Naish, T., Osborn, T., Otto-Bliesner, B., Quinn, T., Ramesh, R., Rojas, M., Shao, X., and Timmermann, A: Information from Paleoclimate Archives, in: Climate Change 2013: The Physical Science Basis. Contribution of Working Group I to the Fifth Assessment Report of the Intergovernmental Panel on Climate Change edited by: Stocker, T. F.,Qin, D., Plattner, G.K., Tignor, M., Allen, S. K., Boschung, J., Nauels, A., Xia, Y., Bex, V., and Midgley, P. M., Cambridge University Press, Cambridge, United Kingdom and New York, NY, USA, 383-464, doi:10.1017/CBO9781107415324.013, 2013.

Mayr, C., Frenzel, B., Friedrich, M., Spurk, M., Stichler, W., and Trimborn, P.: Stable carbon- and hydrogen-isotope ratios of subfossil oaks in southern Germany: methodology and application to a composite record for the Holocene, Holocene, 13, 393-402, doi:10.1191/0959683603hl632rp, 2003.

McCarroll, D. and Loader, N. J.: Stable isotopes in tree rings, Quat. Sci. Rev., 23, 771-801, doi:10.1016/j.quascirev.2003.06.017, 2004.

Miller, G. H., Geirsdottir, A., Zhong, Y., Larsen, D. J., OttoBliesner, B. L., Holland, M. M., Bailey, D. A., Refsnider, K. A., Lehman, S. J., and Southon, J. R.: Abrupt onset of the Little Ice Age triggered by volcanism and sustained by sea-ice/ocean feedbacks, Geophys. Res. Lett., 39, doi:10.1029/2011GL050168, 2012.

Moberg, A., Sonechkin, D. M., Holmgren, K., Datsenko, N. M., and Karlén, W.: Highly variable Northern Hemisphere temperatures reconstructed from low-and high-resolution proxy data, Nature, 433, 613-617, 2005.

Moore, J., Hughen, K., Miller, G., and Overpeck, J.: Little Ice Age recorded in summer temperature reconstruction from vared sediments of Donard Lake, Baffin Island, Canada, J. Paleolimnol., 25, 503-517, 2001.

Naulier, M., Savard, M. M., Bégin, C., Marion, J., Arseneault, D., and Bégin, Y.: Carbon and oxygen isotopes of lakeshore black spruce trees in north-eastern Canada as proxies for climatic reconstruction, Chem. Geol., 374, 37-43, 2014.

Naulier, M.: Développement de séries isotopiques et reconstitution des conditions climatiques estivales du dernier millénaire à partir de tiges subfossiles dans le nord de la forêt boréale Québécoise, Ph.D. thesis, Institut National de la Recherche Scientifique - Eau Terre Environnement, Canada, 237 pp., available at: http://espace.inrs.ca/2610/1/NaulierMaud.pdf (last access: 11 September 2015), 2015.

Naulier, M., Savard, M. M., Bégin, C., Marion, J., Nicault, A., and Bégin, Y.: Temporal instability of isotopes-climate statistical relationships- A study of black spruce trees in northeastern Canada, Dendrochronologia, 34, 33-42, 2015.

PAGES 2K Consortium: Continental-scale temperature variability during the past two millennia, Nat. Geosci., 6, 339-346, doi:10.1038/NGEO1797, 2013.

Payette, S., Filion, L., Delwaide, A., and Bégin, C.: Reconstruction of tree-line vegetation response to long-term climate change, Nature, 341, 429-432, 1989. 
Porter, T., Pisaric, M. J., Field, R., Kokelj, S., Edwards, T. D., deMontigny, P., Healy, R., and LeGrande, A.: Spring-summer temperatures since AD 1780 reconstructed from stable oxygen isotope ratios in white spruce tree-rings from the Mackenzie Delta, northwestern Canada, Clim. Dynam., 42, 1-15, doi:10.1007/s00382-013-1674-3, 2013.

Richter, S. L., Johnson, A. H., Dranoff, M. M., LePage, B. A., and Williams, C. J.: Oxygen isotope ratios in fossil wood cellulose: Isotopic composition of Eocene- to Holocene-aged cellulose, Geochimica and Cosmochimica Acta, 72, 2744-2753, doi:10.1016/j.gca.2008.01.031, 2008.

Robertson, I., Switsur, V. R., Carter, A. H. C., Barker, A. C., Waterhouse, J. S., Briffa, K. R., and Jones, P. D.: Signal strength and climate relationships in $13 \mathrm{C} / 12 \mathrm{C}$ ratios of tree ring cellulose from oak in east England, J. Geophys. Res., 102, 19507-19516, 1997.

Savard, M. M., Bégin, C., Marion, J., Arseneault, D., and Bégin, Y.: Evaluating the integrity of $\mathrm{C}$ and $\mathrm{O}$ isotopes in sub-fossil wood from boreal lakes, Palaeogeogr. Palaeoecol., 348-349, 2131, doi:10.1016/j.palaeo.2012.06.003, 2012.

Shindell, D. T., Schmidt, G. A., Miller, R. L., and Mann, M. E.: Volcanic and solar forcing of climate change during the preindustrial era, J. Climate, 16, 4094-4107, 2003.

Sicre, M. A., Weckström, K., Seidenkrantz, M. S., Kuijpers, A., Benetti, M., Massé, G., Ezat, U., Schmidt, S., Bouloubassi, I., Olsen, J., Khodri, M., and Mignot, J.: Labrador current variability over the last 2000 years, Earth Planet. Sci. Lett., 400, 26-32, 2014.

Sigl, M., McConnell, J. R., Layman, L., Maselli, O., McGwire, K., Pasteris, D., Dorthe, D. J., Steffensen, B.V., Edwards, R, Mulvaney, R., and Kipfstuhl, S. A.: New bipolar ice core record of volcanism from WAIS Divide and NEEM and implications for climate forcing of the last 2000 years. J. Geophys. Res.-Atmos., 118, 1151-1169, 2013.

Thomas, E. K. and Briner, J. P.: Big Round Lake, Baffin Island Varve Thickness Data. IGBP PAGES/World Data Center for Paleoclimatology Data Contribution Series \# 2008-115, NOAA/NCDC Paleoclimatology Program, Boulder CO, USA, 2008.

Thomas, E. K., and Briner, J. P.: Climate of the past millennium inferred from varved proglacial lake sediments on northeast Baffin Island, Arctic Canada, J. Paleolimnol., 41, 209-224, 2009.

Tingley, M. P., Stine, A. R., and Huybers, P.: Temperature reconstructions from tree-ring densities overestimate volcanic cooling, Geophys. Res. Lett., 41, 7838-7845, 2014.

Treydte, K. S., Schleser, G. H., Helle, G., Frank, D. C., Winiger, M., Haug, G. H., and Esper, J.: The twentieth century was the wettest period in northern Pakistan over the past millennium, nature, 440, 1179-1182, 2006.
Trouet, V., Esper, J., Graham, N. E., Baker, A., Scourse, J. D., and Frank, D. C.: Persistent positive North Atlantic Oscillation mode dominated the medieval climate anomaly, Science, 324, 78-80, 2009.

Trouet, V., Scourse, J., and Raible, C.: North Atlantic storminess and Atlantic Meridional Overturning Circulation during the last millennium: reconciling contradictory proxy records of NAO variability, Global Planet. Change, 84, 48-55, 2012.

Trouet, V., Diaz, H., Wahl, E., Viau, A., Graham, R., Graham, N., and Cook, E.: A 1500-year reconstruction of annual mean temperature for temperate North America on decadalto-multidecadal time scales, Environ. Res. Lett., 8, 024008, doi:10.1088/1748-9326/8/2/024008, 2013.

Viau, A. and Gajewski, K.: Reconstructing millennial-scale, regional paleoclimates of boreal Canada during the Holocene, J. Climate, 22, 316-330, 2009.

Viau, A., Ladd, M., and Gajewski, K.: The climate of North America during the past 2000years reconstructed from pollen data, Global Planet. Change, 84, 75-83, 2012.

Vinther, B. M., Buchardt, S. L., Clausen, H. B., Dahl-Jensen, D., Johnsen S. J., Fisher, D. A., Koerner, R. M., Raynaud, D., Lipenkov, V., Andersen, K. K., Blunier, T., Rasmussen, S. O., Steffensen, J. P., and Svensson, A. M.: Holocene shinning of the greenland ice sheet, Nature, Vol. 461, 385-388, 2009.

Vinther, B. M., Jones, P. D., Briffa, K. R., Clausen, H. B., Andersen, K. K., Dahl-Jensen, D., and Johnsen, S. J.: Climatic signals in multiple highly resolved stable isotope records from Greenland, Quaternary Sci. Rev., 29, 522-538, 2010.

Vinther, B. M., Buchardt, S. L., Clausen, H. B., Dahl-Jensen, D., Johnsen S.J ., Fisher, D. A., Koerner, R. M., Raynaud, D., Lipenkov, V., Andersen, K. K., Blunier, T., Rasmussen, S. O., Steffensen, J.P., and Svensson, A. M.: Greenland Ice Sheet Holocene d18O, Temperature, and Surface Elevation, IGBP PAGES/World Data Center for Paleoclimatology Data Contribution Series \# 2011-053, NOAA/NCDC Paleoclimatology Program, Boulder CO, USA, 2011.

Wang, W., Liu, X., Xu, G., Shao, X., Qin, D., Sun, W., An, W., and Zeng, X.: Moisture variations over the past millennium characterized by Qaidam Basin tree-ring $\delta^{18} \mathrm{O}$, Chinese Science Bulletin, 1-6, 2013.

Way, R. G. and Viau, A. E.: Natural and forced air temperature variability in the Labrador region of Canada during the past century, Theor. Appl. Climatol., 121, 413-424, 2014.

Young, G. H. F., McCarroll, D., Loader, N. J., and Kirchhefer, A. J.: A 500-year record of summer near-ground solar radiation from tree-ring stable carbon isotopes, Holocene, 20, 315-324, 2010. 